\title{
GERAKAN KEAGAMAAN DAN PETA AFILIASI IDEOLOGIS PENDIDIKAN ISLAM DI LOMBOK
}

\author{
Saparudin \\ Fakultas Tarbiyah dan Keguruan UIN Mataram \\ Jl. Pendidikan No. 35, Mataram, Nusa Tenggara Barat, 83125 \\ e-mail.s_apank@yahoo.co.id
}

\begin{abstract}
Abstrak: Pendidikan Islam yang sejatinya menjadi wadah keilmuan cenderung lebih merepresentasikan gerakan keagamaan yang menaunginya. Kondisi ini membawa madrasah dan sekolah Islam sebagai instrumen untuk memperkuat eksistensi dan ideologi masing-masing. Kecenderungan ini bersamaan dengan demokratisasi yang dijalankan sejak reformasi 1998, di mana gerakan keagamaan memperoleh ruang dan momentum. Studi ini bertujuan untuk menganalisis dan memetakan kecenderungan dinamika pendidikan Islam di Lombok yang direpresentasikan oleh tiga gerakan keagamaan, masing-masing Nahdlatul Wathan, Muhammadiyah dan Salafi. Sesuai fokus kajian, dipandang relevan metode kualitatif dengan pendekatan sosiologis dijadikan sebagai cognitive framework dalam analisis hasil penelitian. Studi ini membuktikan bahwa hubungan kelompok keagamaan dengan pendidikan bersifat dialektis. Keragaman gerakan keagamaan menentukan corak ideologis pendidikan Islam. Sebaliknya, pendidikan Islam berkontribusi dalam memperkuat perbedaan dan jarak antar kelompok keagamaan.
\end{abstract}

\begin{abstract}
Religious Movement and Ideological Afiliation of Islamic Education in Lombok. Islamic education as scientific means tend to represent more as Islamic movement that supervise them. This problem bring madrasah and Islamic education as the instrument to strengthening their existence and ideology respectively. The fenomena is a long with a democratication which began since reformation era in 1998, wherein Islamic movement gained space and momentum. The aim of this paper is to analyse and map the dynamics of Islamic education in Lombok represented by such three religious movements, as Nahdlatul Wathan, Muhammadiyah and Salafi. This study utilizes qualitative methode with a sociological approach as cognitive framework. This paper argues that the relationship between the Islamic groups with Islamic education is dialectis. The diversity of religious movements determines the ideological pattern of Islamic Education. Conversely, Islamic education contributes to strengthening differences and distance between among denominations.
\end{abstract}

Kata Kunci: Nahdlatul Wathan, Muhammadiyah, Salafi, pendidikan Islam, Lombok 


\section{Pendahuluan}

Pasca jatuhnya presiden Soeharto tahun 1998, gerakan keagamaan memperoleh ruang yang cukup besar, setelah sekian lama tiarap dan melakukan gerakan dalam skala yang terbatas. Memasuki era Reformasi ini, pergulatan antara pendidikan Islam, demokrasi, dan perubahan sosial ditandai oleh munculnya gerakan-gerakan sosial keagamaan di satu sisi, dan menguatnya demokratisasi yang disponsori negara di sisi lain berlangsung semakin intens. ${ }^{1}$ Gerakan-gerakan sosial keagamaan ini tidak hanya lahir dari respons lokalitas-keindonesiaan, sebagaimana Muhammadiyah dan Nahdlatul Ulama (NU), juga hubungan yang bersifat transnasional seperti Jamaah Islamiyah, gerakan Tarbiyah, Majelis Mujahidin Indonesia, Hizbut Tahrir dan Kelompok Salafi Wahabi. ${ }^{2}$ Kondisi ini melahirkan keragaman pola gerakan dan pemikiran, tidak hanya di level nasional, juga lokal. Gerakangerakan ini dipersatukan oleh persepsi bahwa pendidikan merupakan wadah strategis untuk memperkuat dan mengembangkan eksistensinya. Dapat disaksikan bagaimana kompleksitas dari keragaman dan dinamika pendidikan Islam, tidak hanya sebagai wadah semaian ideologi masing-masing, juga kontestasi antar gerakan keagamaan.

Di tingkat lokal, menguatnya demokrasi bersamaan dengan diterapkannya otonomi daerah justru memberikan ruang yang semakin terbuka bagi elit agama - tuan guru untuk memperluas peran dalam berbagai sektor, terutama sosial politik. ${ }^{3}$ Kondisi ini berdampak terhadap semakin berkurangnya peran-peran sosial keagamaan yang selama ini menjadi basis otoritas dan modal sosial. Pada akhirnya membuka peluang bagi gerakan Salafi untuk mengisi kekosongan, dan memberikan pola keberagamaan "baru" bagi masyarakat Lombok. Sementara Muhammadiyah yang lebih terkosentrasi pada lembaga pendidikan nampaknya bukanlah hambatan yang berarti bagi Salafi untuk bernegosiasi, bahkan karena memiliki persamaan doktrin teologis, menjadi partner dalam kondisi aspek tertentu. Akhirnya, sebagaimana dapat disaksikan pola keberagamaan masyarakat Islam Lombok tidak hanya semakin plural, juga semakin kompleks bersamaan dengan keinginan masing-masing gerakan keagamaan untuk memperoleh otoritas dan kontrol sosial.

Keragaman gerakan internal umat Islam yang semakin dinamis dan kompleks, mengaburkan relevansi dikotomi tradisional-modernis. Gambaran Esposito tentang kehadiran gerakan tradisionalis NU sebagai bentuk perlawanan terhadap gerakan modernis Muhammadiyah ${ }^{4}$ semakin sulit diterjemahkan dalam konteks Islam kontemporer Indonesia.

${ }^{1}$ Robert W. Hefner, "Islamic Schools, Social Movements and Democrasy in Indonesia," dalam Robert W. Hefner (ed.), Making Modern Muslims the Politics of Islamic Education in Southeast Asia (Honolulu: University of Hawai Press, 2009), h. 55-98.

${ }^{2}$ Martin van Bruinessen, Contemporary Developments in Indonesian Islam Explaining the "Conservative Turn" (Singapore: ISEAS, 2013), h. 21-53.

3Jeremy J. Kingsley, "Redrawing Lines of Religious Authority in Lombok, Indonesia," dalam Asian Journal of Social Science, 42 (2014), h. 661.

${ }^{4}$ John L. Esposito, Ensiklopedi Oxford, Dunia Modern Islam, Jilid III, cet. 2 (Bandung: Mizan, 
Lebih jauh, kategorisasi lembaga pendidikan jihadis dan fundamentalis berdasarkan ideologi gerakan, dan tradisional dan modern berdasarkan geografis sebagaimana temuan Kohno, ${ }^{5}$ jelas tidak relevan. Hasil analisis Bruinessen memberikan penjelasan bahwa di tengah keragaman gerakan keagaman di Indonesia, Muhammadiyah yang awalnya disebut gerakan reformis nampaknya kehilangan energi, dan kembali ke sikap konservatif. Sementara kelompok tradisional semakin intens melakukan diskursus akademik tentang isu-isu reformis Islam, ${ }^{6}$ yang dalam banyak hal memperoleh penguatan dan relevansi dengan isu-isu kebangsaan dan pluralisme. Atas dasar ini pelabelan organisasi Muslim tradisionalis dalam konteks pendidikan terhadap organisasi ini menurut Bartholomew merupakan cara pandang yang tidak fair, dan merupakan karikatur dikotomis yang tidak relevan. ${ }^{7}$ Demikian juga sebaliknya, menyebut Muhammadiyah sebagai organisasi modern tidak seluruhnya benar. Muhamadiyah menurutnya dalam konteks pandangan teologis lebih tradisional ketimbang Nahdlatul Wathan (NW). ${ }^{8}$

Di tengah keragaman gerakan keagamaan di atas, pendidikan Islam bukanlah realitas yang tunggal. Keragaman dan dinamikanya ditentukan oleh berbagai realitas yang dihadapi. Perbedaan madrasah dan sekolah Islam tidak semata-mata dipengaruhi oleh perbedaan paham keagamaan, melainkan juga pemahaman ideologis terhadap paham keagamaan oleh kelompok keagamaan. Memahami ritme dan keragamannya mensyaratkan penulis menggali konstruksi dan relasi keduanya, di mana pendidikan sebagai entitas yang dapat dipengaruhi dan mempengaruhi di dalamnya. Memahami konteks dan kecenderungan empiris, berikut identitas ideologis masing-masing lembaga pendidikan, dapat dikatakan bahwa hubungan kelompok keagamaan dengan pendidikan bersifat dialektis. Keragaman gerakkan keagamaan menentukan corak ideologis Pendidikan Islam. Sebaliknya, pendidikan Islam berkontribusi dalam memperkuat perbedaan dan jarak antar kelompok keagamaan.

Ditempatkan dalam konteks fenomena di atas, artikel ini difokuskan pada kecenderungan dinamika Islam Lombok yang direpresentasikan oleh tiga gerakan keagamaan, masingmasing Nahdlatul Wathan, Muhammadiyah dan Salafi. Selanjutnya, juga dihadirkan dampaknya terhadap keragaman corak ideologis pendidikan yang ditawarkan masingmasing. Pada bagian akhir, secara ringkas dijelaskan bagaimana lembaga pendidikan

2002), h. 207. Lihat juga Howard M. Federspiel, "The Muhammadiyah: A Study of an Orthodox Islamic Movement in Indonesia," dalam Indonesia, No. 10, (1970), h. 58.

${ }^{5}$ Takeshi Kohno, "Political Background of Islamic Education Institutions and the Reach of the State in Southeast Asia," dalam Studia Islamika, Vol. 16, No. 2, 2009, h. 208-209.

${ }^{6}$ Martin van Bruinessen, "Introduction: Contemporery Developments in Indonesian Islam and the "Conservative Turn" of the Early Twenty-First Centery," dalam Martin van Bruinessen (ed.), Contemporary Developments in Indonesian Islam Explaining the "Conservative Turn" (Singapore: ISEAS, 2013), h. 20.

7John Ryan Bartholomew, Alif Lam Mim Kearifan Masyarakat Sasak, terj. Imron Rosyidi (Yogyakarta: Tiara Wacana, 2001), h. 32-34.

${ }^{8}$ Ibid., h. 32-34. 
tersebut digunakan untuk memperkuat eksistensi komunal masing-masing kelompok keagamaan. Dengan menempatkan tiga kelompok keagamaan dan berikut lembaga pendidikan yang ditawarkannya, dapat dijadikan sebagai entry point untuk membaca dan mengkaji kecenderungan keberagamaan dan afiliasi ideologis pengembangan pendidikan secara luas.

\section{Metode Penelitian}

Studi ini merupakan penelitian lapangan yang dilakukan pada latar alamiah dengan lokus gerakan keagamaan dan implikasinya terhadap corak ideologis pendidikan Islam di Lombok. Berangkat dari fokus kajian ini, dipandang relevan metode kualitatif dengan pendekatan sosiologi dijadikan sebagai cognitive framework dalam analisis hasil penelitian. Penggunaan kualitatif karena merupakan fenomena sosial yang melibatkan interaksi dan identitas sosial yang berbasis keagamaan. Sealur dengan metode ini, pendekatan sosiologi yang memberikan perhatian pada hubungan interaksi dan konstruksi sosial, ${ }^{9}$ digunakan untuk melihat bagaimana relasi dan interaksi gerakan keagamaan dalam mengkonstruk identitas ideologis masing-masing melalui dan dalam pendidikan.

Konsisten dengan pendekatan di atas, secara operasional peneliti tidak berhenti pada realitas yang mudah diamati, seperti konstruksi ideologi keagamaan dalam kurikulum, bahan ajar, media, siswa, dan simbol-simbol tertentu, melainkan juga struktur psikologis dan sosiologis pimpinan organisasi keagamaan, aparatur madrasah dan sekolah Islam (guru keagamaan) dan pembina kegiatan ekstrakurikuler, yang inheren dan mengitari subyek penelitian. Demikian juga terkait kontestasi dan fragmentasi sosial, tidak berhenti pada pilihan madrasah dan sekolah Islam tertentu dapat dipahami sebagai dorongan ideologi tertentu, tetapi lebih dari itu latar belakang yang mendasari pilihan tersebut merupakan bagian yang urgen. Cara kerja demikian diharapkan pergumulan internal dan penguatan identitas melalui muatan ideologi keagamaan yang diartikulasikan di lingkungan lembaga pendidikan dapat diamati secara utuh dalam proses penelitian.

Pemilihan sumber data dalam penelitian ini ditentukan secara purposive sampling, dengan mempertimbangkan kesesuaiannya dengan kepentingan penelitian. Sesuai dengan karakteristiknya, purposive sampling digunakan untuk memastikan bahwa sumber data atau informan yang dipilih memiliki informasi yang dibutuhkan. ${ }^{10}$ Keragaman tipologi subyek yang diteliti dan diseleksi berdasarkan basis atau afiliasi ideologi keagamaan yang dimiliki, ditentukan, dan dianggap merepresentasikan subyek dan mencapai ketercukupan. ${ }^{11}$

${ }^{9}$ Michael S. Northcott, "Sociological Approaches," dalam Peter Connoly (ed.) Approaches to the Study of Religion (t.t.p.: A \& C Black, 1999), h. 193-194.

${ }^{10}$ Maguerite G. Lodico, et al., Methods in Educational Research (t.t.p.: John Wiley \& Sons, 2010), h. 163.

${ }^{11}$ Royce A. Singleton dan Bruce C Straits, Approaches to Social Research (New York: Oxford University Press, 1999), 158. 
Berdasarkan identifikasi terhadap corak identitas kelembagaan pendidikan Islam di Lombok, ada tiga lembaga pendidikan yang dijadikan objek kajian, yaitu Nahdlatul Wathan, Muhammadiyah dan Salafi. Tiga kelompok keagamaan dipandang merepresentasikan corak ideologi keagamaan yang berkembang di daerah ini. Agar penelitian ini dapat menggali data secara utuh dan holistik, teknik wawancara mendalam (indept interview), observasi dan dokumentasi digunakan secara simultan.

\section{Hasil dan Pembahasan}

\section{Performa Islam di Pulau Seribu Masjid}

Pelekatan identitas sebagai "Pulau Seribu Masjid" bagi pulau Lombok tidaklah berlebihan. Walaupun tidak diketahui secara pasti sejak kapan mulai digunakan, istilah ini tidak hanya merefleksikan secara fisik jumlah masjid yang mencapai 3.928 (74\%) dari $5.288^{12}$ unit masjid di Nusa Tenggara Barat, juga tingginya religiusitas masyarakat di pulau ini. Berbagai prestasi yang disandang tokoh Islam Lombok, seperti Syaikh Ibn Hajar al-Khaitamy (Tuan Guru Umar Kelayu), Syaikh Wildan, Syaikh Khalid sebagai pengajar di Makkah, dan sejumlah Tuan Guru alumni Makkah dan Mesir turut memperkuat identitas tersebut. ${ }^{13}$ Tetapi secara ideologis, menurut Kari Telle, hal ini juga dapat dipahami untuk membedakan dengan Bali yang dikenal dengan "Pulau Dewata."14 Manifestasi keberagamaan masyarakat $\operatorname{sasak}^{15}$ (suku asli masyarakat Lombok) yang disimbolkan dengan masjid mencerminkan Islam memiliki tempat yang fundamental dalam struktur psikologis maupun sosiologis masyarakat sasak.

Berbanding lurus dengan penyandingan identitas di atas, dominannya umat Islam turut mempengaruhi jumlah dan pertumbuhan tempat ibadah. Masyarakat sasak yang merupakan suku asli pulau Lombok ${ }^{16}$ hampir keseluruhannya menganut agama Islam. Data statistik menunjukkan bahwa umat Islam mencapai 96.4\%, dari keseluruhan penduduk.

${ }^{12}$ Sisanya 1.360 (26\%) Masjid berada di pulau Sumbawa. Lihat Badan Statistik NTB, Nusa Tenggara Barat dalam Angka tahun 2013, h. 223.

${ }^{13}$ Departemen P dan K NTB, Pengaruh Budaya Asing terhadap Kehidupan Sosial Budaya Masyarakat Sasak di Daerah NTB (Mataram: Departemen P dan K,1996), h. 35.

${ }^{14}$ Kari Telle, "Canging Spiritual Landscapes and Religious Politics on Lombok," dalam Brigitta Hauser-Schaublin and David D. Harnish (ed.), Between Harmony and Discrimination Negotiating Religious Identities within Majority-Minority Relationship in Bali and Lombok (Leiden Boston: Brill, 2014), h. 35.

${ }^{15}$ Tentang asal usul suku Sasak lihat H. Sudirman, Gumi Sasak dalam Sejarah (Bagian I) (Lombok: KSU Primaguna-Pusat Studi dan Kajian Budaya, 2012), h. 1, 16; Djalaludin Arzaki, et al. Nilai-nilai Agama dan Kearifan Budya Lokal Suku Bangsa Sasak dalam Pluralisme Bermasyarakat: Sebuah Kajian Antthropologis-Sosiologis-Agamis (Mataram: Redam, 2001), h. 4-7.

${ }^{16}$ Istilah Sasak dan Lombok walaupun dua hal yang berbeda, ditengarai secara etimologi memiliki ikatan yang erat. Kedua kata tersebut berasal dari sa'sa' loombo, sa' berarti satu, dan lombo berarti lurus, sehingga Sasak Lombok dimaknai satu-satunya kelurusan. Lihat Sudirman, Gumi Sasak dalam Sejarah, h. 16. 
Kendati jumlahnya lebih kecil dibanding penganut agama Islam, agama Hindu mencapai 2.5\%, jauh lebih besar dibanding agama Buddha 0.5\%, Agama Kristen Protestan 0.4\%, dan Kristen Katolik 0.2\%. Berkuasanya Kerajaan Karang Asem Bali selama 154 tahun, dari tahun 1740 sampai dengan $1894,{ }^{17}$ memiliki kontribusi terhadap besarnya jumlah penganut agama Hindu di Pulau Lombok.

Tidak dapat dipastikan sejak kapan orang sasak mengenal Islam. Sebagaimana ditengarai Mohammad Noor, et al., selain kesulitan melacak jejak sejarah masuknya Islam di pulau ini, juga kesulitan memetakan antara mitos dan fakta sejarah yang tertuang dalam cerita-cerita legenda dan mistis lainnya. Penuturan-penuturan yang ada selama ini sangat beragam dan agak sulit dikompromikan satu sama lain menjadi ringkasan proses yang berkesinambungan. ${ }^{18}$ Namun dari berbagai studi yang dilakukan mengenai islamisasi di wilayah ini, umumnya memiliki persepsi yang sama bahwa Islam masuk ke Lombok secara lebih jelas sekitar abad ke-16, ${ }^{19}$ dengan tokoh utamanya Sunan Prapen, ${ }^{20}$ setelah Islam diperkenalkan oleh bapaknya Sunan Giri tahun $1545 .{ }^{21}$ Namun persepsi ini tidak menafikan bahwa adanya interaksi orang Muslim Jawa, Sulawesi, Banten, dan Gresik pada abad ke-13 dengan masyarakat sasak. ${ }^{22}$ Mengingat interaksi ini hanya kepentingan perdagangan, bukan kepentingan dakwah, patut diduga sebagai alasan mengapa abad ini cenderung tidak dijadikan sebagai awal islamisasi di daerah ini.

Sebelum Islam diperkenalkan, masyarakat sasak menganut aliran kepercayaan yang disebut boda. Boda bukanlah agama Buddha, tetapi kepercayaan yang bertumpu pada anasir Animisme, Dinamisme, dan Antromofisme. Sebab itu, pemujaan dan penyembahan terhadap roh-roh leluhur dan berbagai dewa lainnya merupakan fokus utama keagamaan Sasak-Boda. ${ }^{23}$ Dalam perkembangannya, praktik Boda tergusur ke daerah pegunungan dan hutan bersamaan dengan infiltrasi budaya luar, terutama agama Islam.

Dengan latarbelakang demikian, ketika Islam mulai diperkenalkan, masyarakat sasak memperlihatkan pola keberagamaan yang sinkritis. Bartholomew mengintrodusir bahwa campuran antara kepercayaan-kepercayaan Austronesia dengan Islam merupakan keberislaman masyarakat sasak di masa awal. ${ }^{24}$ Pola ini pada tahap selanjutnya ber-

${ }^{17}$ Lalu Lukman, Pulau Lombok dalam Sejarah Ditinjau dari Aspek Budaya, cet. 3 (Jakarta, 2005), h. 28.

${ }^{18}$ Mohammad Noor, et al., Visi Kebangsaan Religius Refleksi Pemikiran dan Perjuangan Tuan Guru Kyai Haji Muhammad Zainuddin Abdul Madjid 1904-1997 (Jakarta: Ponpes NW Jakarta, 2014), h. 75.

${ }^{19}$ Sven Cederroth, The Spell of the Ancestors and the Power of Makkah: A Sasak Community on Lombok (Sweden: ACTA Universitis Gothoburgensis, 1981), h. 32.

${ }^{20}$ Lalu Lukman, Pulau Lombok dalam Sejarah Ditinjau dari Aspek Budaya (Mataram: t.p., 2005), h. 6-7.

${ }^{21}$ Cederroth, The Spell of the Ancestors, h. 32.

${ }^{22}$ Sudirman, Gumi Sasak, h. 19.

${ }^{23} I b i d .$, h. 1. Bandingkan dengan Sven Cederroth, The Spell of the Ancestors, h. 32-33.

${ }^{24}$ Bartholomew, Alif Lam Mim, h. 95. 
metamorfosis menjadi Islam Wetu Telu, ${ }^{25}$ sebuah tipe Islam sinkretis antara kepercayaankepercayaan Animisme, Hindu dan Muslim. ${ }^{26}$ Meskipun mereka mengaku sebagai Muslim, secara terus menerus memuja para leluhur, berbagai dewa roh dan lainnya dalam lokalitas mereka.

Walaupun tidak diterima secara keseluruhan, sebagaimana yang nampak dalam keberagamaan Islam Wetu Telu, agam Islam memang relatif mudah masuk dan dipraktikkan masyarakat sasak. Hal ini dimungkinkan karena dua hal. Pertama, secara konseptual ajaran Islam cocok dengan, dan tidak mengancam struktur sosial dan kepercayaan-kepercayaan lokal. ${ }^{27} \mathrm{Kedua}$, pola dakwah yang diterapkan mencerminkan strategi yang fleksibel yang cenderung toleran terhadap budaya lokal. Ketiga, Islam yang dibawakan Sunan Prapen bercita rasa sufisme-mistisme, sehingga dalam aspek tertentu memiliki relevansi dengan ajaran nenek moyang orang sasak. ${ }^{28}$

Gencarnya proses dakwah yang dilakukan, pada tahap selanjutnya melahirkan Islam Waktu Lima, yang secara dikotomis vis a vis Wetu Telu. Istilah Waktu Lima digunakan sebagai kerangka teoretik untuk menggambarkan Islam yang sempurna, yakni pola keberagamaan yang ditandai ketaatan yang tinggi terhadap ajaran-ajaran Islam, sebagaimana Muslim pada umumnya. ${ }^{29}$ Munculnya dua tipe keberagamaan ini, sebagai implikasi dari dua jalur dengan karakteristik islamisasi yang berbeda. Harnish menengarai, Islam yang datang dari Lombok Utara bercorak sufisme, yang selanjutnya menghasilkan tipe Wetu Telu, dan Islam yang datang dari Timur bercorak ortodoks, yang selanjutnya melahirkan tipe Waktu Lima.$^{30}$ Jadi praksis, penggunaan dikotomi ini untuk menegasikan satu dengan yang lain. Didukung oleh institusi pemerintah dan berbagai organisasi sosial keagamaan, Waktu Lima sebagai kelompok dominan, secara terus menerus menjadikan Wetu Telu sebagai objek dakwahnya. ${ }^{31}$ Implikasinya, Wetu Telu menjadi minoritas, dan kini hanya dapat dijumpai di daerah pedalaman tertentu di Lombok Utara dan Selatan. Kemungkinan berdasarkan kecenderungan ini, Cederroth sampai pada pandangan bahwa pada masa

\footnotetext{
${ }^{25}$ Penggunaan istilah ini lebih detail lihat Erni Budiwanti, Islam Sasak Wetu Telu versus Waktu Lima (Yogyakarta: LKiS, 2000). Belakangan ditengarai istilah Wetu Telu sebagai produk kolonial Belanda, yang dihadap-hadapkan dengan Islam ideal Waktu Lima. Lihat juga Sven Cederroth, The Spell of the Ancestors, h. 2-5.

${ }^{26}$ Departemen P dan K, Adat Istiadat Daerah Nusa Tenggara Barat (Jakarta: Departemen P dan K, 1978). Tentang praktik-praktik Islam Wetu Telu, lihat Erni Budiwanti, Islam Sasak, h. 139195.

${ }^{27}$ Bartholomew, Alif Lam Mim, h. 95.

${ }^{28}$ Sudirman, Gumi Sasak, h. 25-26

${ }^{29}$ Budiwanti, Islam Sasak, h. 7.

${ }^{30}$ David Harnish, "Worlds of Wayang Sasak: Music, Performance, and Negotiations of Religion and Modernity," dalam Asian Music, 34, No. 2 (2003), h. 91-120.

${ }^{31}$ Lebih jelas lihat Team Penyusunan Monografi NTB, Monografi Daerah Nusa Tenggara Barat (Jakarta: Departemen P dan K, 1977), h. 79-86. Lihat juga Budiwanti, Islam Sasak, h. 289-335.
} 
itu Islam Waktu Lima bukanlah pilihan asli, dan dipandang tidak suitable dengan masyarakat Sasak. ${ }^{32}$

Terlepas dari dikotomi di atas, Islam telah menemukan bentuk dan tempatnya di masyarakat sasak, sebagaimana dipraktikkan secara luas.Wetu Telu bukanlah entitas yang berdiri sendiri, sebagaimana dipahami banyak pihak, namun lebih sebagai proses transisi dari agama Hindu menuju Islam yang ideal. Tidak pelak Wetu Telu secara terus menerus menjadi objek dakwah Waktu Lima. Dalam konteks ini, Tuan Guru memiliki posisi strategis, pengaruh, dan berkontribusi terhadap pembentukan "Islam ideal," sekaligus memperbesar otoritas Tuan Guru atas elit adat bangsawan. Keberhasilan ini menurut MacDougall, tidak terlepas dari dukungan pemerintah atas dakwah Tuan Guru sebagai timbal balik atas dukungan dan keterlibatannya dalam Golkar (partai penguasa) dan penumpasan PKI. ${ }^{33}$ Kondisi ini berbeda dengan masa kolonialisme Belanda, di mana kaum bangsawan yang menopang Wetu Telu memperoleh tempat yang istimewa, yang dipertentangkan dengan Waktu Lima, dalam waktu yang bersamaan tidak hanya menjadi tantangan bagi Tuan Guru, juga membatasi ruang Tuan Guru dalam melakukan dakwah. ${ }^{34}$

Kondisi di atas menegasikan kondisi awal Islam yang dipraktikkan masyarakat sasak. Perkembangan Islam di Lombok, dan pembentukan keberislaman masyarakat Sasak tidak bisa lepas peran dan kontribusi NW sebagai organisasi terbesar di daerah ini. Organisasi ini telah meletakkan suatu landasan bagi proses penerjemahan Islam ke dalam sistem dan budaya masyarakat sasak. Secara ideologis keagamaan, dalam banyak hal, NW sejajar dengan NU di Jawa ${ }^{35}$ atau disebut Bartholomew bahwa NW sebagai saudara muda NU, ${ }^{36}$ meski berbeda dalam hal pola indoktrinasi dan militansi. Di bawah pendiri dan sekaligus pimpinan Tuan Guru Zainuddin Abdul Majid, organisasi ini melalui gerakan dakwah dan lembaga pendidikan yang dimiliki, menjadi garda terdepan dalam membentuk struktur dan kultur sosial keagamaan Muslim Lombok, diikuti NU, Muhammadiyah, dan belakangan gerakan Salafi.

\section{Pelembagaan Islam dan Keragaman Gerakan Keagamaan}

Terciptanya interaksi dinamis sebagai akibat dari berkembangnya berbagai aspek

${ }^{32}$ Cederroth, The Spell of the Ancestors, h. 2-3.

${ }^{33}$ John M. MacDougall, "Kriminalitas dan Ekonomi Politik Keamanan di Lombok," dalam Henk Schulte, et al. (ed.), Politik Lokal Indonesia, terj. Bernard Hidayat (Jakarta: KITLV, 2007), h. 379.

${ }^{34}$ Tentang dialektika Tuan Guru dengan elit bangsawan di satu sisi, dan kolonial Belanda di sisi lain, lihat Harnish, Worlds of Wayang Sasak, h. 94-95.

${ }^{35}$ Jajat Burhanuddin, "Pesantren, Madrasah, dan Islam di Lombok," dalam Jajat Burhanuddin dan Dina Afrianty (ed.), Mencetak Muslim Modern Peta Pendidikan Islam Indonesia (Jakarta: RajaGrafindo Persada, 2006), h. 45.

${ }^{36}$ Bartholomew, Alif Lam Mim, h. 30. Lihat juga Munawir Husni, Nahdlatul Wathan Restorasi Islam Indonesia Timur (Yogyakarta: Binafsi Publihser, 2015), h. 52-53. 
kehidupan yang ditandai oleh semakin tingginya tuntutan hidup, meningkatnya teknologi transportasi dan komunikasi, memberi peluang terjadinya relasi dan pembentukan komunal baru dalam masyarakat Islam sasak. Sebagaimana disaksikan, lahirnya lembaga keagamaan seperti NW, Muhammadiyah, dan disusul gerakan Salafi membuktikan bahwa telah terbangun struktur keagamaan yang menandai kebersamaan dan sekaligus perbedaan di dalamnya. Keberadaan tiga lembaga keagamaan ini, berikut sistem keyakinannya, sangat mewarnai praktik dan ritual keagamaan masyarakat sasak. Mengingat lembaga keagamaan tersebut dibangun atas dasar nilai ekstalogis-teologis, dalam interaksinya dalam banyak hal dan kondisi tertentu menurut Dadang melibatkan dan menampakkan sentimen ideologis. ${ }^{37}$

Dalam konteks Lombok, pergerakan sosial (social movement) dan komunalisme yang didorong oleh ideologi keagamaan menjadi bagian terpenting dalam keberagamaan umat Islam. Keberagaman masyarakat Islam di daerah ini, sebagaimana halnya di daerah lain, memiliki corak dan karakteristik yang tidak tunggal. Ini merupakan wujud dari artikulasi doktrin Islam yang beragam. Fenomena ini merupakan sintesa dari doktrin normativitas dan dimensi kesejarahan. Dari sini melahirkan pemahaman dan pemaknaan atas doktrin agama yang berbeda, yang pada akhirnya melahirkan perilaku keberagamaan yang berbeda pula. $^{38}$

Memperhatikan keragaman ormas Islam dan gerakan keagamaan di Lombok akhirakhir ini sesungguhnya merupakan kecenderungan umum di daerah lain. Untuk memahaminya harus ditempatkan dalam skala yang lebih luas, dimana geneologi intelektual Muslim Indonesia dengan Timur Tengah di satu sisi, dan pergulatannya dengan lokalitas budaya Indonesia ${ }^{39}$ dipandang sebagai faktor yang memengaruhi keragaman lembaga keragamaan tersebut. Dalam hal relasi dengan Timur Tengah secara lebih rinci Yon Machmudi berhasil mengidentifikasi adanya tiga gelombang relasi intelektual yang mempengaruhi keragaman tersebut. Pertama, generasi alumni Timur Tengah pada akhir penjajahan Belanda, yang terdiri atas dua kelompok, yaitu alumni Makkah yang cenderung tradisional dan alumni Kairo yang cenderung modernis. Dua kecenderungan ini selanjutnya terpresentasikan dalam dua organisasi Nahdatul Ulama dan Muhammadiyah. Kedua, generasi pasca kemerdekaan, yang ditandai oleh munculnya pemikiran rasional dan liberal, yang terwakili oleh Harun Nasution dan Abdurrahman Wahid. Ketiga, generasi tahun 1970-1980-an yang ditandai oleh munculnya pemikiran fundamentalis, yang dipengaruhi oleh pemikiran Sayyid Quthb dan Ikhwan al-Muslim. ${ }^{40}$

\footnotetext{
${ }^{37}$ Dadang Akhmad, Sosiologi Agama (Bandung: Rosdakarya, 2000), h. 29.

${ }^{38}$ M. Mukhsin Jamil, et al., Nalar Islam Nusantara: Studi Islam ala Muhammadiyah, alIrshad, Persis, dan NU (Jakarta: Diktis Departemen Agama RI, 2007), h. 1.

${ }^{39}$ Pergumulan ini dijelaskan oleh Howard M. Federspiel pada pendahuluan bukunya Islam and Ideology in the Emerging Indonesian State the Persatuan Islam (Persis) 1923-1957 (Leiden: Brill, 2001).

${ }^{40}$ Yon Machmudi, "Islamism and Political Participation: A Case Study of Jemaah Tarbiyah in Indonesia," (The paper is presented at the international workshop on Islamism and Political
} 
Islam sebagaimana dipraktikkan dan dipahami, menampilkan sejumlah variasi dalam masyarakat sasak. Diversifikasi ini tidak hanya terjadi pada masyarakat urban sebagaimana ditulis Bartholomew, ${ }^{41}$ juga masyarakat pedesaan. Sebagaimana di tempat lain, dinamika pemikiran dan pemahaman atas doktrin Islam tidaklah monolitik. Perubahanperubahan yang terjadi memang bukanlah khas wilayah ini, tetapi sudah merupakan fenomena yang secara umum menandai kehidupan masyarakat Islam. Jika pada masa awal, Islam dihadap-hadapkan dengan sinkritisme Wetu Telu, kini mengalami dialektika dan kontestasi antar berbagai kelompok secara internal.

Menyaksikan keberagamaan masyarakat sasak saat ini, dapat direpresentasikan oleh hadirnya lembaga keagamaan. Selain NW, sejumlah organisasi keagamaan seperti NU, Muhammadiyah, Hidayatullah, Tarbiyah Islamiyah, Lembaga Dakwah Islamiyah Indonesia, Dewan Masjid Indonesia, dan gerakan Salafi ${ }^{42}$ eksis di daerah ini. ${ }^{43}$ Kendatipun corak pengamalan keagamaan NW dan NU merupakan yang dominan, masyarakat sasak tidaklah stagnan dan monolitik, perlahan menunjukkan dinamika yang terbuka terhadap corak Islam yang berbeda. Penerimaan masyarakat sasak atas gerakan Salafi mengindikasikan kecenderungan ini. Walaupun tidak terorganisir secara kelembagaan ${ }^{44}$ sebagaimana halnya organisasi keagamaan yang lain, dengan militansi islamisme yang kuat, gerakan ini kini mewarnai dinamika keagamaan masyarakat sasak. Perjumpaan antara ideologi Salafi yang dianggap pendatang yang lebih agresif dengan paham mainstrem NW, di samping NU yang secara ideologis merasa mapan, memengaruhi perubahan sikap dan perilaku keberagamaan masyarakat sasak. Walaupun masih menjadi kelompok minoritas, namun sekolah-sekolah yang berafiliasi dengan Salafi yang secara terus menerus didukung oleh Arab Saudi, tetap akan memiliki perkembangan dan memberikan pengaruh terhadap perubahan sosial keagamaan di Lombok.

Menurut Syamsul Arifin, proses-proses sosial tersebut juga menimbulkan pertarungan wacana untuk memperebutkan hegemoni Islam yang dipandang paling otentik. Proses ini pada gilirannya melahirkan organisasi keagamaan di kalangan umat Islam pada awal abad ke-20, seperti Muhammadiyah, Persis, NU, dan al-Irsyad. Tidak pelak fenomena institusionalisasi Islam ke dalam wadah organisasi menarik perhatian para peneliti. ${ }^{45}$

Participation in Southeast Asia: Global Contexts and Trends held by the Lowy Institute for International Policy International Workshop, Sydney, 8-9 April 2010).

${ }^{41}$ Bartholomew, Alif Lam Mim, h. 86-87.

${ }^{42}$ Istilah salafi secara etimologis dan terminologis lihat Ibn Manzhur, Lisân al-Arab (Mesir: Dâr al-Ma'arif, t.t.), h. 2068; 'Abd al-Salâm al-Suhaimi, Kun Salafiyan 'ala al-Jâddah (Madinah al-Nabawiyah, t.p., 1423), h. 72-73.

${ }^{43}$ Bashori A. Hakim, "Wawasan Kebangsaan Kelompok Salafi di Nusa Tenggara Barat: Studi Kelompok Salafi di Ponpes Dârush-Syifâ,," dalam Harmoni Jurnal Multikultural \& Multireligius, Vol. 13, No. 2, h. 78.

${ }^{44}$ Lihat Wizârah al-Tarbiyah wa al-Ta'lîm, al-Tauhîid (Riyad:Wizârah al-Ma'ârif, 1999), h. 9.

${ }^{45}$ Syamsul Arifin, "Agama sebagai Instrumen Gerakan Sosial Tawaran Teoritik Kajian Fundamentalisme Agama," dalam Studia Philosophica et Theologica, Vol. 8 No. 1, 2008, h. 41. 
Pelembagaan ini selanjutnya memengaruhi sejumlah elemen untuk digunakan sebagai wadah pertarungan, terutama lembaga pendidikan.

Dialektika di atas berimplikasi terhadap keragaman lembaga pendidikan Islam bagi masyarakat Islam Lombok. Terwadahi oleh ormas keagamaan, lembaga pendidikan, baik dalam bentuk madrasah maupun sekolah Islam berkembang dan eksis sebagai sentral cultural framing tradisi dan gerakan keagamaan yang melibatkan sentimen ideologis teologis. Sebagaimana akan ditunjukkan, baik NW, Muhammadiyah maupun Salafi memiliki identitas masing-masing dan mendesiminasikan secara terus menerus dalam berbagai aspek pendidikan, yang pada akhirnya melahirkan corak dan orientasi ideologis pendidikan yang beragam.

\section{Afiliasi Ideologis Pendidikan Islam di Lombok}

Hadir di tengah keragaman keberagamaan masyarakat di atas, lembaga pendidikan memperoleh tempat yang strategis. Lembaga pendidikan baik formal maupun nonformal, tidak hanya sebagai institusi ilmiah, juga sebagai wadah penegasan identitas ideologis. Karena itu memahami lembaga pendidikan Islam di Lombok mensyaratkan mengkaji ideologi keagamaan masing-masing kelompok atau ormas penyelenggaranya. Seperti yang akan diperlihatkan di bagian berikutnya, tidak ada lembaga pendidikan Islam baik dalam bentuk madrasah dan sekolah Islam berproses tanpa ideologi di belakangnya.

Keberadaan berbagai gerakan keagamaan, berikut identitasnya, memiliki kontribusi yang signifikan dalam perkembangan pendidikan Islam di pulau Lombok. Data Kemenag NTB menunjukkan, dari 2.584 madrasah dalam berbagai tingkatannya, hanya 66 madrasah atau $17 \%$ yang berstatus negeri. Selebihnya 2.518 atau $83 \%$ berstatus swasta. ${ }^{46}$ Selain mencerminkan peran serta masyarakat yang tinggi, data ini juga menunjukkan tingginya ekspektasi masyarakat terhadap lembaga pendidikan Islam. Logis, karena persentasi di atas tidak terbatas gambaran kuantitas, juga gambaran betapa besarnya harapan masyarakat menitipkan harapannya bagi masa depan anak-anak mereka. Relevan, di saat lembaga pendidikan yang dikelola pemerintah sangat terbatas, dan tidak memiliki kapasitas yang memadai, maka lembaga pendidikan swasta tampil memberikan jawaban persoalan ini. Tidak pelak, dari 252.216 siswa pada lembaga pendidikan di lingkungan Kemenag NTB, 223.590 atau $87 \%$ ditampung di madrasah swasta. Sedangkan dari total 201.162 siswa di Lombok, 186.689 siswa ditampung pada madrasah swasta, sisanya $14.473^{47}$ di madrasah negeri.

Jika dihubungkan dengan sekolah Islam yang bernaung di Kemendikbud, maka

\footnotetext{
${ }^{46}$ Kementerian Agama NTB, Rekapitulasi Data Madrasah Tahun 2014.

${ }^{47}$ Kementerian Agama NTB, Rekapitulasi Jumlah Siswa Madrasah 2014. Jumlah ini berbanding terbalik dengan kondisi siswa pada lembaga pendidikan di bawah Kemendikbud NTB, dari 823.034 siswa, hanya 130.413 atau 16\% siswa sekolah swasta. Lihat Badan Statistik NTB, Nusa Tenggara Barat dalam Angaka tahun 2013, h. 139.
} 
peran lembaga pendidikan berbasis keagamaan akan lebih strategis. Untuk tingkat SLTA sebagai contoh, dari 274 sekolah, 98 atau 36\% merupakan sekolah Islam, dan 69 sekolah berada di Lombok. ${ }^{48}$ Jumlah ini akan terus mengalami peningkatan sejalan dengan mobilitas dan dinamika keagamaan masyarakat Islam di daerah ini. Mengingat perkembangan lembaga pendidikan di Kabupaten Lombok Utara belum masuk data base Kemenag NTB sebagai akibat masa transisi pemekaran daerah, memungkinkan memperjelas perbandingan ini. Dalam konteks ini, keberadaan sekolah Islam yang seluruhnya berstatus swasta, akan secara terus menerus memberikan warna pendidikan, baik dalam skala lokal maupun nasional.

Pertumbuhan dan perkembangan lembaga pendidikan di atas, sebagai implikasi dari dinamika gerakan sosial kegamaan seperti NW, NU, Muhammadiyah, Marakit Ta'lim, Salafi dan gerakan Tarbiyah yang berafiliasi dengan Ikhwan al-Muslim. Kehadiran kelompok keagamaan ini menunjukkan trend yang tidak hanya semakin beragam, juga dinamika internal dan eksternal yang semakin kompleks. Kondisi ini mempengaruhi corak pendidikan Islam, tidak hanya secara kelembagaan, juga orientasi ideologisnya. Baik NW, Muhammadiyah, maupun gerakan Salafi memiliki lembaga pendidikan baik formal maupun non-formal. Sejak berdiri tahun $1937,{ }^{49} \mathrm{NW}$ telah memiliki 1088 di Nusa Tenggara Barat, ${ }^{50}$ atau $42 \%$ dari 2.584 total madrasah di daerah ini. Dominannya madrasah NW, tidak terlepas dari peran ormas ini dalam sejarah panjang pembentukan masyarakat Islam di Lombok. Sedangkan Muhammadiyah hingga penelitian ini dilakukan masih memiliki 45 lembaga pendidikan dalam berbagai tingkatanya di NTB, dan hanya 18 berada di Lombok. ${ }^{51}$ Sedangkan gerakan Salafi walaupun datang lebih belakang, diprediksi memiliki15-20 lembaga pendidikan yang tersebar di berbagai tempat dalam berbagai tingkatannya. Memperhatikan dinamika Salafi di daerah ini, jumlah ini akan terus bertambah, bersamaan dengan semakin terbukanya gerakan ini dalam penyelenggaraan pendidikan formal, dan dukungan eksternal Timur Tengah.

Semakin berkembangnya lembaga pendidikan Islam di Lombok dipengaruhi oleh sejumlah faktor. Pertama, semakin tinggi dan meningkatnya religiusitas masyarakat, yang ditandai oleh semakin banyaknya tempat ibadah, kelompok keislaman, dan seremonial keagamaan. Kedua, kekhawatiran yang semakin meningkat atas pengaruh negatif modernisasi dan globalisasi terhadap life style, akhlak dan moralitas dunia remaja. Ketiga, semakin membaiknya perhatian pemerintah terhadap lembaga pendidikan Islam. Keempat, dalam konteks NW, peran spiritual dan kultural Tuan Guru, dan akomodatifnya Aswaja yang ditawarkan terhadap tradisi dan budaya lokal. Sedangkan dalam konteks Muhammadiyah, kemampuan manajerial yang menawarkan pendidikan modern memiliki

\footnotetext{
${ }^{48}$ Dinas Pendidikan dan Kebudayaan NTB, Daftar SMA Negeri/Swasta Se-NTB Tahun 2013. ${ }^{49}$ Noor, et al., Visi Kebangsaan Religius, h. 172.

${ }^{50}$ PB. NW Pancor, Rekap Data Lembaga Pendidikan NW Se-NTB tahun 2014.

${ }^{51}$ PWM NTB, Rekapitulasi Data Amal Usaha Muhammadiyah Se-NTB tahun 2013.
} 
daya tarik tersendiri bagi masyarakat Lombok. Sementara bagi gerakan Salafi, adanya dukungan ideologis dan finansial dari Timur Tengah (terutama Arab Saudi) dan tingginya komitmen dan konsistensi keagamaan yang ditunjukkan. Komitmen nampak dalam penggunaan simbol-simbol keislaman, keunggulan dalam bahasa Arab dan tahfiz al-Qur'an, dan komitmen dakwah. Di samping itu terintegrasinya lembaga pendidikan Salafi ke dalam sistem pendidikan nasional, juga memperkuat akslerasi sekolah dan madrasah Salafi di daerah ini. ${ }^{52}$

Sebagaimana yang akan diuraikan, keberadaan lembaga-lemabaga pendidikan tersebut menjadi wadah yang efektif bagi penyebaran dan penguatan identitas keagamaan, dan akhirnya menjadi identitas kultural. Untuk sampai pada kepentingan ini, ketiga kelompok keagamaan tersebut telah merumuskan secara sistematis substansi keislaman yang diajarkan di lembaga pendidikan masing-masing, baik dalam bentuk mata pelajaran, bahan ajar, media, maupun berbagai kegiatan ekstrakurikuler. Keragaman identitas ini selanjutnya mewarnai dinamika masing-masing di tengah ekspektasi internal maupun eksternalnya. Identitas ideologis merupakan corak yang menjadi distingsi antar lembaga pendidikan, dan membentuk dan menempatkan mereka ke dalam orientasi yang berbeda.

Pemetaan corak gerakan keagamaan berbasis ideologi yang dijalankan, setidaknya ada tiga tipe ideologi keagamaan yang diartikulasikan dalam pendidikan Islam, yaitu tradisionalis, modernis eklektif, dan konservatif modernis. Pilihan term ini di tengah kompleksitas watak dan kecenderungan lembaga pendidikan Islam, di satu sisi melakukan modernisasi dan transformasi, di sisi lain tetap mempertahankan keragaman identitas masing-masing. Penggunaan berbagai terminologi yang tumpang tindih terhadap gerakan yang berbasis ideologi keagamaan dalam berbagai literatur, turut mempengaruhi kesulitan penulis untuk menggunakan istilah yang tepat dalam pemetaan karakteristik ideologi keagamaan dalam pendidikan. Meski demikian, tiga istilah ini digunakan sebagai kerangka teoretik untuk menjelaskan kecenderungan tiga lembaga yang dijadikan subyek studi berdasarkan basis ideologinya. Mengingat artikulasi ini melibatkan dimensi dan tendensi teologis, psikologis dan sosiologis, kerangka teoretik ini tidak bersifat dikotomik yang kaku, tetapi lebih menggambarkan kecenderungan umum yang bersifat fleksibel.

Pertama, tradisionalis, yaitu corak yang mengartikulasikan dan toleran terhadap budaya lokal dalam praktik keagamaan. ${ }^{53}$ Istilah tradisionalis pernah digunakan Steenbrink, ${ }^{54}$ Deliar Noer, ${ }^{55}$ dan Bruinessen ${ }^{56}$ dalam menggambar NU sebagai organisasi keagamaan

\footnotetext{
${ }^{52}$ Saparudin, "Salafism, State Recognition, and Social Tension: New Trend Islamic Education in Lombok," dalam Ulumuna: Journal of Islamic Studies, Vol. 21, No. 1, 2007.

${ }^{53}$ Bruinessen (ed.), Contemporary Developments in Indonesian Islam, h. 22.

${ }^{54}$ Karel A. Steenbrink, Pesantren Madrasah dan Sekolah Pendidikan Islam Kurun Modern, cet. 2 (Jakarta: LP3ES, 1994).

${ }^{55}$ Deliar Noer, Gerakan Moderen Islam di Indonesia 1900-1942, cet. 8 (Jakarta: LP3ES, 1996).

${ }^{56}$ Bruinessen (ed.), Contemporary Developments, h. 25-26.
} 
yang membangun dan memanifestasikan identitas ideologisnya berdasarkan unsur-unsur kultural. Berbasis pada pendidikan dan tradisi pesantren, kharisma kiai, penerimaan atas mistisme, penekanan pada fikih, dan pemanfaat tradisi dalam berbagai ritual keagamaan, merupakan indikasi yang dijadikan dasar oleh tiga peneliti tersebut dalam pelekatan corak tradisionalis pada NU. Jika disejajarkan dengan NU, maka ideologi Ahlussunnah Waljamaah yang diusung NW dapat dikategorikan ke dalam corak ini.

Sebagai gerakan tradisionalis, beberapa indikasi yang diidentifikasi Bruinessen tersebut, merupakan bagian yang melekat dan dimanifestasikan dalam keseluruhan tradisi keberagamaan NW. Seperti dijelaskan di bagian sebelumnya, berbasis pada pesantren, Tuan Guru Zainuddin berhasil merumuskan dan merangkai berbagai elemen budaya dan tradisi menjadi bagian dari ruang artikulasi nilai dan ajaran Islam. Berbagai ritual seperti perayaan maulid Nabi, ziarah kubur, pembacaan talkin dan tahlilan bagi orang yang meninggal, dan berbagai upacara keagamaan lainnya merupakan bagian yang tidak terpisahkan. Bahkan penerimaan dan apresiasinya terhadap tasawuf ia tunjukkan dengan mendirikan tarekat Nahdlatul Wathan berupa hizb NW, yang selanjutnya menjadi karakter utama organisasi ini. Rangkaian keyakinan dan ritual yang berbasis tradisi ini, mengantarkan Tuan Guru Zainuddin memiliki kharisma dan otoritas religius dan tradisional yang tinggi.

Kedua, modernis eklektif, yaitu seraya melakukan modernisasi dengan menekankan rasionalitas, dan juga mempertahankan tradisi salaf yang bersifat normatif konservatif. Corak ini direpresentasikan oleh kecenderungan Muhammadiyah. Meski pada tingkat tertentu, pandangan keagamaan Muhammadiyah memiliki titik temu dengan Salafi, namun secara metodologis dan pemikiran Muhammadiyah menjunjung peran akal dalam melakukan modernisasi lembaga pendidikannya.Yunahar Ilyas mengatakan bahwa salah satu poin pokok ideologi Muhammadiyah adalah gerakan tajdid, yang mengandung makna purifikasi dan dinamisasi, dimana keduanya harus berjalan bersamaan. Purifikasi berkaitan akidah (pemurnian dari syirik), ibadah (pemurnian dari bidah), dan akhlak (pemurnian dari yang menyimpang). Sedangkan dinamisasi adalah modernisasi di bidang keduniawian. Bidah hanya ada dalam bidang ibadah mahdhah, bukan pada wilayah sosial budaya. Karena itu menurut Ilyas, Muhammadiyah memposisikan diri sebagai Islam moderat atau washathiah, tidak radikal dan tidak liberal. Muhammadiyah berpegang tawassuth (tengah-tengah), tawazzun (seimbang), dan ta'addul (adil). ${ }^{57}$

Eklektivitasnya nampak dari kemampuan Muhammadiyah, yang dalam diskursus lebih luas, mempertemukan konservatisme Timur Tengah (Salafi) dengan progresif-rasionalitas Barat, yang kemudian diterjemahkan secara lokal di Indonesia. Puritanisme merupakan salah satu elemen reformasi Muhammadiyah, di tengah elemen-elemen modernisme, terutama lembaga pendidikannya. Spirit Ibn 'Abd al-Wahhâb dan Ibn Taimiyyah dicampur

57"Begini Ringkasan Ideologi Muhammadiyah Menurut Yunahar Ilyas," dalam http://www. suaramuhammadiyahid/2017/05/06. 
dengan spirit rasional dan modernis Muhammad 'Abduh, dan dibawa secara bersamaan dalam konteks Indonesia. ${ }^{58}$ Istilah modernis eklektif sedikit lebih moderat jika dibandingkan dengan istilah purificationist-modernist ${ }^{59}$ yang digunakan Bryner dalam menggambarkan gerakan Muhammadiyah, meski dengan asumsi dan latar belakang yang sama.

Dukungan Muhammadiyah terhadap moderniasi lembaga pendidikan, menggelorakan tajdid dan ijtihad, dan akomodatifnya terhadap modernisme Barat, mengindikasikan Muhammadiyah menawarkan ideologi modernis yang khas di antara dua kecenderungan di atas. Sejak awal berdirinya, watak modernis eklektifnya nampak dari penerimaannya terhadap pola pendidikan Belanda yang diwujudkan dalam sekolah HIS Met de Qur'an, ${ }^{60}$ yang selanjutnya menjadi emberio sekolah Islam moderen, tidak hanya di internal Muhammadiyah, juga lembaga lain di tanah air. Pemaknaan tajdid yang tidak hanya bermakna purifikasi, juga dinamisasi dan modernisasi, yang selanjutnya diwujudkan dalam pengembangan paradigma dan lembaga pendidikan, memperkuat corak eklektif ini. Dapat dimengerti, meskipun secara teologis memiliki kedekatan dengan Salafi, namun pada saat yang bersamaan mendorong warganya untuk responsif terhadap modernisasi, terutama dalam lembaga pendidikan.

Ketiga, konservatif modernis, yaitu ideologi yang meski melakukan modernisasi lembaga pendidikan, namun watak normatif konservatif tetap terjaga, seraya melakukan penegasian terhadap rasionalitas. Bahkan dalam banyak hal tipe ini bersifat antagonis terhadap rasionalitas Barat. Istilah ini digunakan Hefner dalam menggambarkan Madrasah Mukmin Ngeruki. Berdasarkan kurikulum yang menggabungkan pengetahuan umum dan agama, dan metode yang digunakan menurut Hefner, madrasah yang dipimpin Abu Bakar Ba'asyir ini memperlihatkan kecenderungan modern, meskipun tetap menempatkan ajaran Islam sebagai ilmu dan sistem yang terbaik dalam semua aspek kehidupan, termasuk dalam bernegara. ${ }^{61}$ Penerimaan lembaga pendidikan formal, berikut kurikulumnya, juga menjadi salah satu alasan Hefner memasukkan lembaga ini ke dalam karakteristik konservatif modernis. Disejajarkan dengan kecenderungan dan operasional Madrasah Mukmin Ngeruki, Madrasah Abu Hurairah dapat disebut sebagai gerakan ideologi konservatif modernis. Kurikulum yang digunakan mengindikasikan bahwa madrasah ini mencerminkan sikap kooperatif dengan menerima kurikulum Kemendikbud dan Kemenag, meski tetap menempatkan ilmu keislaman sebagai muatan yang dominan. Memperhatikan konstruksinya,

${ }^{58} \mathrm{Ahmad}$ Najib Burhani, "Liberal and Conservative Discourses in The Muhammadiyah: The Struggle for The Face of Reformist Islam in Indonesia," dalam Martin van Bruinessen (ed.), Contemporary Developments, h. 135-138. Lihat juga Arief Subhan, Lembaga Pendidikan Islam Indonesia Abad ke20 (Jakarta: Kencana, 2012), h. 145-146.

${ }^{59}$ Karen Bryner, "Piety Projects: Islamic School for Indonesia's Urban Middle Class" (Disertasi, The Graduate School of Arts and Science, Columbia University, 2013), h. 36-38.

${ }^{60}$ Subhan, Lembaga Pendidikan, h. 151-152.

${ }^{61}$ Robert W. Hefner, Schooling Islam: Modern Muslim Education (Princeton University Press, 2007), h. 84-85. 
kurikulum yang digunakan memiliki kesamaan dengan kurikulum yang digunakan Madrasah Mukmin Ngeruki. ${ }^{62}$ Sedangkan dilihat dari aspek relasi ideologisnya, Madrasah Abu Hurairah dapat disejajarkan dengan ideologi transnasional, sebagaimana digunakan beberapa peneliti dalam menggambarkan infiltrasi gerakan Salafi wahabi di Indonesia. Karena itu, keberadaan Ponpes Abu Hurairah tidak dapat dibaca dalam konteks sosiologis Lombok semata-mata, karena memang ideologi yang ditanamkan bukanlah khas daerah ini. Gerakan ini memiliki spektrum yang sangat luas tidak hanya lokal, nasional, juga internasional.

Dengan kandungan yang lebih luas, Madrasah dan Sekolah yang diselenggarakan ketiga gerakan di atas, di dalamnya tidak hanya disemaikannya ideologi, juga yang jauh lebih penting adalah terbangunnya struktur kaderisasi yang lebih sistematis. Ini menandakan bahwa apa yang disebut Altrusser sebagai apparatus ideology sedang bekerja. Baik Madrasah NW, Sekolah Muhammadiyah maupun Madrasah Abu Hurairah sedang berproses dalam pembentukan dan penyiapan kader-kader, yang selanjutnya menjadi penggerak sustainablitas ideologi di masa depan. Jika apparatus ideology digunakan Althusser dalam konteks negara, maka dalam konteks ini dapat disejajarkan dengan kader ideologi di internal Islam.

Mencermati konstelasi teologis-ideologis, kehadiran Salafi yang demikian dinamis menjadikan Muhammadiyah tidak lagi menjadi diskursus utama gerakan Islam di NTB. Ada dua hal yang menunjukkan kecenderungan ini. Pertama, di saat lembaga pendidikan Salafi seperti Abu Hurairah menunjukkan peningkatan yang signifikan dalam sepuluh lima tahun terakhir, lembaga pendidikan Muhammadiyah justru mengalami penurunan peminat yang cukup drastis. Kedua, dalam diskursus wacana keislaman di tingkat lokal, gerakan Muhammadiyah luput, kalau bukan terabaikan, baik sebagai objek studi maupun respons terhadap isu-isu kontemporer. Implikasinya, meski perkembangannya relatif baru, berbagai hasil studi empiris tentang gerakan Salafi lebih mudah ditemui, dibandingkan studi-studi empiris tentang Muhammadiyah di daerah ini. Dalam konteks nasional, kecenderungan ini digambarkan Bruinessen sebagai hilangnya energi Muhammadiyah sebagai gerakan reformis, dan kembali ke sikap konservatif. ${ }^{63}$

Di sisi lain, genelogi intelektual Tuan Guru dan pergumulan identitas dengan Hinduisme yang demikian panjang, tidak mudah bagi Muhammadiyah maupun Salafi untuk menembus benteng yang disebut sinkritisme beragama. Statisnya, kalau bukan gagalnya Muhammadiyah dalam melakukan ideologisasi di Lombok, selain karena faktor di atas, indoktrinasi yang hanya mengandalkan lembaga pendidikan formal terbukti tidak efektif. Sebaliknya gerakan Salafi yang pada awalnya hanya mengandalkan pengajian-pengajian dan pondok (atau lebih populer ma'had), dalam faktanya hanya melahirkan konfrontasi dan bahkan konflik dengan kelompok mainstrem NU dan NW. Dalam kondisi seperti ini,

${ }^{62}$ Charlene Tan, Islamic Education and Indoctrination: the Case in Indonesia (London: Routledge, 2014), h. 47-58.

${ }^{63}$ Bruinessen, "Introduction," dalam Bruinessen (ed.) Contemporary Developments, h. 20. 
nampak kalangan Salafi secara cepat membaca ekpektasi masyarakat dan memunculkan kesadaran, bahwa dibutuhkan perpaduan antara pendidikan nonformal dan formal. Respons ini selanjutnya ia wujudkan dalam penyelenggaraan sejumlah lembaga pendidikan mulai dari tingkat Sekolah Dasar hingga SLTA. Strategi ini nampaknya cukup efektif, hasilnya sebagaimana yang akan dijelaskan, memiliki dampak yang signikan terhadap perkembangan Salafi di daerah ini. Lembaga pendidikan non formal dalam bentuk pondok digunakan sebagai wadah yang secara efektif untuk melakukan internalisasi bahkan doktrinasi ideologi, sementara pendidikan formal di samping memperkuat doktrinasi tersebut, juga mengakomodasi harapan masyarakat, agar anak-anak mereka dapat mengakses pendidikan yang lebih luas dan tinggi.

Menempatkan diri di tengah dialektika di atas, meski secara ideologis dan afiliasi kelembagaan berbeda dari konsep dan gerakan mainstream di Lombok, seperti NU dan NW, lembaga pendidikan yang diinisiasi kalangan Salafi memperoleh apresiasi oleh tidak hanya masyarakat pedesaan, tapi merambah ke masyarakat menengah perkotaan. Seperti yang ditunjukkan Sekolah dan Madrasah Abu Hurairah Mataram, dalam beberapa tahun terakhir menjadi sekolah alternatif di tengah ribuan sekolah dan madrasah yang didirikan NU, NW dan sebagian Muhammadiyah, yang jauh lebih awal dioperasikan di daerah ini. Sekolah dan madrasah Salafi dipandang mampu menawarkan alternatif baru dengan mempromosikan keunggulannya di bidang tahfiz al-Qur'an dan bahasa Arab.

Dikotomi modernis dan tradisionalis juga pernah digunakan dalam Bruinessen dalam melihat tipologi pendidikan Islam masa awal. Modernis direpresentasikan oleh Perserikatan Muhammadiyah dan tradisionalis direpresentasikan oleh Nahdlatul Ulama. ${ }^{64}$ Berbasis urban area, dan penerimaan Muhammadiyah terhadap subjek dan sekolah modern nampaknya menjadi alasan kuat mengapa Bruinessen memandang Muhammadiyah sebagai tipikal pendidikan Islam modernis. Sedangkan NU yang berbasis rural area, dan cenderung mempertahankan tradisi dan menitikberatkan pada ilmu agama mencerminkan tipikal tradisionalis. Namun di era kontemporer menurut Bruinessen, hadirnya Pesantren Salafi atau yang ia sebut Saudi Salafism dan beberapa gerakan independen, memberikan warna tersendiri, meskipun belum begitu jelas dalam kategori mana gerakan ini ia masukkan, kecuali hanya menyebut reformis alternatif dan gerakan independen. Untuk kategori terakhir, gerakan NII dan DII dianalisis sebagai bukti empiris.

Keragaman gerakan internal umat Islam yang semakin dinamis dan kompleks, mengaburkan relevansi dikotomi tradisional-modernis. Gambaran Esposito tentang kehadiran gerakan tradisionalis NU sebagai bentuk perlawanan terhadap gerakan modernis Muham-

${ }^{64}$ Martin van Bruinessen, "Traditionalist and Islamist Pesantrens in Contemporery Indonesia," dalam Farish A. Noor, Yoginder Sikand dan Martin van Bruinessen (ed.), The Madrasah in Asia Political Activism and Transnational Linkages (Amsterdam: Amsterdam University Press, 2008), h. $218,223-225$. 
madiyah ${ }^{65}$ semakin sulit diterjemahkan dalam konteks Islam kontemporer Indonesia. Hasil analisis Bruinessen memberikan penjelasan bahwa di tengah keragaman gerakan keagaman di Indonesia, Muhammadiyah yang awalnya disebut gerakan reformis nampaknya kehilangan energi, dan kembali ke sikap konservatif. Sementara kelompok tradisional semakin intens melakukan diskursus akademik tentang isu-isu reformis Islam, ${ }^{66}$ yang dalam banyak hal memperoleh penguatan dan relevansi dengan isu-isu kebangsaan dan pluralisme. Atas dasar ini pelabelan organisasi Muslim tradisionalis dalam konteks pendidikan terhadap organisasi ini menurut Bartholomew merupakan cara pandang yang tidak fair, dan merupakan karikatur dikotomis yang tidak relevan. ${ }^{67}$ Demikian juga sebaliknya, menyebut Muhammadiyah sebagai organisasi modern tidak seluruh benar. Muhammadiyah menurutnya dalam konteks pandangan teologis lebih tradisional ketimbang NW. ${ }^{68}$

Besarnya arus Islam transnasional, sebagaimana gerakan Salafi yang memiliki titik singgung, berimplikasi terhadap ambivalensi Muhammadiyah dalam mempertegas

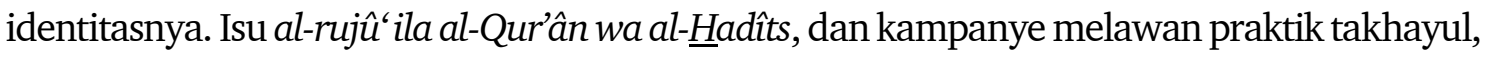
bidah dan khurafat yang pernah diperjuangkan di masa awal, yang kini diambil alih oleh kelompok Salafi, sudah dianggap tidak relevan lagi bagi Muhammadiyah. Masuknya sejumlah elit Salafi dan gerakan Tarbiyah ke dalam tubuh Muhammadiyah menjadikan Muhammadiyah dalam posisi dilema ideologis; sebagai dan dianggap kelompok konservatif di satu sisi, dan modernis di sisi lain. ${ }^{69}$ Mempertimbangkan dinamika Muhammadiyah, dan kecenderungannya yang tidak lagi memberikan energi pada persoalan teologis saat ini, memperkuat argumen bahwa secara ideologis Muhammadiyah bercorak modernis eklektif.

Meski berdasarkan basis ideologis dapat dibedakan dalam tiga tipe yang berbeda, namun dalam konteks kelembagaan pendidikan baik tradisionalis, modernis eklektif, maupun modernis konservatif dipersatukan oleh respons bahwa pertama, mereka samasama sebagai lembaga formal, dan berada di bawah payung sistem pendidikan nasional. Kedua, sebagai implikasi dari respons pertama, mereka menerima dan menjalankan sejumlah mata pelajaran non-agama sesuai dengan kurikulum pemerintah. Hal ini dimengerti sebagai indikasi bahwa baik NW, Muhammadiyah maupun Salafi secara kelembagaan dalam posisi yang sama sebagai kelompok modernis. Kategori ini hanya dapat dipertentangkan dengan corak fundamentalis yang menurut Kohno memiliki keraguan untuk mengadopsi materi non-keagamaan, dan selalu menyediakan ruang lebih besar dalam pengembangan kajian keislaman di luar muatan kurikulum regulernya di sisi lain. ${ }^{70}$

\footnotetext{
${ }^{65}$ Esposito, Ensiklopedi Oxford: Dunia Modern Islam, h. 207. Lihat juga Federspiel, "The Muhammadiyah," h. 58.

${ }^{66}$ Bruinessen, "Introduction: Contemporery Developments," h. 20.

${ }^{67}$ Bartholomew, Alif Lam Mim, h. 32-34.

${ }^{68}$ Ibid.

${ }^{69}$ Burhani, Liberal and Conservative Discourses, h. 135-138.

${ }^{70}$ Kohno, Political Background, h. 208-209.
} 
Kecenderungan di atas dalam batas tertentu mendukung tipologi yang dirumuskan Kohno, meski tidak mendukung sebagian yang lain. Berdasarkan tendensi ideologisnya, Kohno membagi lembaga pendidikan Islam di Indonesia ke dalam empat tipologi. ${ }^{71}$ Pertama, sekolah tradisionalis, yang umumnya dikelola oleh Nahdlatul Ulama dalam bentuk madrasah dan pesantren, dimana rural area sebagai basisnya. Kedua, sekolah modernis, yang umumnya dikelola Muhammadiyah, dimana urban area sebagai basisnya. Ketiga, sekolah fundamentalis seperti pesantren dan madrasah Hidayatullah, dan al-Mukmin Ngeruki. Keempat, sekolah jihadis, walaupun agak sulit untuk diidentifikasi, tipe ini dapat dilihat dari beberapa alumninya, seperti alumni pesantren al-Mukmin yang bergabung dalam Jama'ah Islamiyah, dan Pesantren al-Islam Lamongan yang terlibat dalam Bom Bali tahun 2002. Tipe ketiga dan keempat, nampaknya tidak sepenuhnya relevan dalam menggambarkan dinamika pendidikan Islam Indonesia kontemporer. Penerimaan Pondok pesantren yang awalnya dianggap fundamentalis radikal atas kebijakan pemerintah dengan mendirikan lembaga pendidikan formal dan penggunaan kurikulum nasional mengindikasikan adanya perubahan orientasi meski identitas ideologisnya tetap dipertahankan.

\section{Penutup}

Keragaman gerakkan keagamaan menentukan corak ideologis pendidikan Islam. Sebaliknya, pendidikan Islam berkontribusi dalam memperkuat perbedaan dan jarak antar kelompok keagamaan. Berdasarkan ideologi yang ditawarkan, hal ini setidaknya dapat dipetakan ke dalam tiga corak pendidikan Islam. Pertama, tradisionalis, yaitu corak yang mengartikulasikan dan toleran terhadap budaya lokal dalam praktik keagamaan. Kedua, konservatif modernis, yaitu ideologi yang meski melakukan modernisasi lembaga pendidikan, namun watak normatif konservatif tetap terjaga, seraya melakukan penegasian terhadap rasionalitas. Ketiga, modernis eklektif yaitu seraya melakukan modernisasi dengan menekankan rasionalitas, dan juga mempertahankan tradisi salaf yang bersifat normatif konservatif. Corak ini direpresentasikan oleh kecenderungan Muhammadiyah. Meski berdasarkan basis ideologis dapat dibedakan dalam tiga tipe yang berbeda, namun dalam konteks kelembagaan pendidikan baik tradisionalis, modernis eklektif, maupun modernis konservatif dipersatukan oleh respons bahwa mereka sama-sama sebagai lembaga formal dan berada di bawah payung sistem pendidikan nasional. Mereka menerima dan menjalankan sejumlah mata pelajaran non-agama sesuai dengan kurikulum pemerintah. Hal ini dimengerti sebagai indikasi bahwa baik NW, Muhammadiyah maupun Salafi secara kelembagaan dalam posisi yang sama sebagai kelompok modernis.

${ }^{71} I$ Ibid., h. 205-207. 


\section{Pustaka Acuan}

Akhmad, Dadang. Sosiologi Agama. Bandung: Rosdakarya, 2000.

Al-Suhaimi, 'Abd al-Salâm. Kun Salafiyan 'ala al-Jâddah. Madinah al-Nabawiyah: t.p., 1423 H.

Arifin, Syamsul. "Agama sebagai Instrumen Gerakan Sosial Tawaran Teoritik Kajian Fundamentalisme Agama," dalam Studia Philosophica et Theologica, Vol. 8, No. 1, 2008.

Arzaki, Djalaludin. et al. Nilai-nilai Agama dan Kearifan Budya Lokal Suku Bangsa Sasak dalam Pluralisme Bermasyarakat: Sebuah Kajian Antthropologis-Sosiologis-Agamis. Mataram: Redam, 2001.

Bartholomew, John Ryan. Alif Lam Mim Kearifan Masyarakat Sasak, terj. Imron Rosyidi. Yogyakarta: Tiara Wacana, 2001.

Bruinessen, Martin van. "Introduction: Contemporery Developments in Indonesian Islam and The "Conservative Turn" of The Early Twenty-First Centery," dalam Martin van Bruinessen (ed.). Contemporary Developments in Indonesian Islam Explaining the "Conservative Turn. Singapore: ISEAS, 2013.

Bruinessen, Martin van. "Traditionalist and Islamist Pesantrens in Contemporery Indonesia," dalam Farish A. Noor, Yoginder Sikand dan Martin van Bruinessen (ed.). The Madrasah in Asia Political Activism and Transnational Linkages. Amsterdam: Amsterdam University Press, 2008.

Bruinessen, Martin van. Contemporary Developments in Indonesian Islam Explaining the "Conservative Turn". Singapore: ISEAS, 2013.

Bryner, Karen. "Piety Projects: Islamic School for Indonesia's Urban Middle Class." Disertasi, The Graduate School of Arts and Science, Columbia University, 2013.

Budiwanti, Erni. Islam Sasak Wetu Telu versus Waktu Lima. Yogyakarta: LKiS, 2000.

Burhanuddin, Jajat. "Pesantren, Madrasah, dan Islam di Lombok," dalam Jajat Burhanuddin dan Dina Afrianty (ed.). Mencetak Muslim Modern: Peta Pendidikan Islam Indonesia. Jakarta: RajaGrafindo Persada, 2006.

Cederroth, Sven. The Spell of the Ancestors and the Power of Mekkah: A Sasak Community on Lombok. Sweden: ACTA Universitis Gothoburgensis, 1981.

Departemen P dan K NTB. Pengaruh Budaya Asing terhadap Kehidupan Sosial Budaya Masyarakat Sasak di Daerah NTB. Mataram: Departemen P dan K,1996.

Departemen P dan K. Adat Istiadat Daerah Nusa Tenggara Barat. Jakarta: Departemen P dan K, 1978.

Esposito, John L. Ensiklopedi Oxford: Dunia Modern Islam, Jilid III, cet. 2. Bandung: Mizan, 2002.

Federspiel, Howard M. "The Muhammadiyah: a Study of an Orthodox Islamic Movement in Indonesia," dalam Indonesia, No. 10, (1970).

Federspiel, Howard M. Islam and Ideology in the Emerging Indonesian State the Persatuan Islam (Persis) 1923-1957. Leiden: Brill, 2001. 
Hakim, Bashori A. "Wawasan Kebangsaan Kelompok Salafi di Nusa Tenggara Barat: Studi Kelompok Salafi di Ponpes Dârush-Syifâ'," dalam Harmoni Jurnal Multikultural \& Multireligius, Vol. 13, No. 2.

Harnish, David. "Worlds of Wayang Sasak: Music, Performance, and Negotiations of Religion and Modernity," dalam Asian Music 34, No. 2 (2003).

Hefner, Robert W. "Islamic Schools, Social Movements and Democrasy in Indonesia," dalam Robert W. Hefner (ed.). Making Modern Muslims the Politics of Islamic Education in Southeast Asia. Honolulu: University of Hawai Press, 2009.

Hefner, Robert W. Schooling Islam: Modern Muslim Education. Princeton University Press, 2007.

Husni, Munawir. Nahdlatul Wathan Restorasi Islam Indonesia Timur. Yogyakarta: Binafsi Publihser, 2015.

Ibn Manzhur. Lisân al-Arab. Mesir: Dâr al-Ma'arif, t.t.

Jamil, M. Mukhsin. et al., Nalar Islam Nusantara: Studi Islam ala Muhammadiyah, al-Irsyad, Persis, dan NU. Jakarta: Diktis Departemen Agama RI, 2007.

Kingsley, Jeremy J. "Redrawing Lines of Religious Authority in Lombok, Indonesia," dalam Asian Journal of Social Science, 42 (2014).

Kohno, Takeshi. "Political Background of Islamic Education Institutions and the Reach of the State in Southeast Asia," dalam Studia Islamika, Vol. 16, No. 2, 2009.

Lodico, Maguerite G. et al. Methods in Educational Research. t.t.p.: John Wiley \& Sons, 2010.

Lukman, Lalu. Pulau Lombok dalam Sejarah Ditinjau dari Aspek Budaya, cet. 3. Jakarta, 2005.

Lukman, Lalu. Pulau Lombok dalam Sejarah Ditinjau dari Aspek Budaya. Mataram, 2005.

MacDougall, John M. "Kriminalitas dan Ekonomi Politik Keamanan di Lombok," dalam Henk Schulte, et al. (ed.) Politik Lokal Indonesia, terj. Bernard Hidayat. Jakarta: KITLV, 2007.

Machmudi, Yon. "Islamism and Political Participation: A Case Study of Jemaah Tarbiyah in Indonesia." The paper is presented at the international workshop on Islamism and Political Participation in Southeast Asia: Global Contexts and Trends held by the Lowy Institute for International Policy International Workshop, Sydney, 8-9 April 2010.

Noer, Deliar. Gerakan Modern Islam di Indonesia 1900-1942, cet. 8. Jakarta: LP3ES, 1996.

Noor, Mohammad. et al., Visi Kebangsaan Religius Refleksi Pemikiran dan Perjuangan Tuan Guru Kyai Haji Muhammad Zainuddin Abdul Madjid 1904-1997. Jakarta: Ponpes NW Jakarta, 2014.

Northcott, Michael S. "Sociological Approaches," dalam Peter Connoly (ed.) Approaches to the Study of Religion. t.t.p.: A \& C Black, 1999.

Saparudin. "Salafism, State Recognition, and Social Tension: New Trend Islamic Education in Lombok," dalam Ulumuna: Journal of Islamic Studies, Vol. 21, No. 1, 2007. 
Singleton, Royce A. dan Bruce C Straits. Approaches to Social Research. New York: Oxford University Press, 1999.

Steenbrink, Karel A. Pesantren Madrasah dan Sekolah Pendidikan Islam Kurun Moderen, cet. 2. Jakarta: LP3ES, 1994.

Subhan, Arief. Lembaga Pendidikan Islam Indonesia Abad ke-20. Jakarta: Kencana, 2012.

Sudirman. Gumi Sasak dalam Sejarah (Bagian I). Lombok: KSU Primaguna-Pusat Studi dan Kajian Budaya, 2012.

Tan, Charlene. Islamic Education and Indoctrination: the Case in Indonesia. London: Routledge, 2014.

Telle, Kari. "Canging Spiritual Landscapes and Religious Politics on Lombok," dalam Brigitta Hauser-Schaublin and David D. Harnish (ed.). Between Harmony and Discrimination Negotiating Religious Identities within Majority-Minority Relationship in Bali and Lombok. Leiden Boston, Brill, 2014.

Wizârah al-Tarbiyah wa al-Ta'lîm. al-Tauhîid. Riyad:Wizârah al-Ma'ârif, 1999.

"Begini Ringkasan Ideologi Muhammadiyah Menurut Yunahar Ilyas," dalam http://www. suaramuhammadiyahid/2017/05/06. 